\title{
Development of community participation based on behaviour in managing participative programs
}

\author{
Pengembangan partisipasi masyarakat berbasis perilaku dalam \\ pengelolaan program partisipatif
}

\author{
Dedy Hermawan \& Simon Sumanjoyo Hutagalung \\ Department of Public Administration, Faculty of Social and Political Sciences, Universitas Lampung \\ Address: Jalan Prof. Dr. Sumantri Brojonegoro No. 1, Bandar Lampung, Lampung 35145 \\ E-mail: dedy.hermawan@fisip.unila.ac.id \& simon.sumanjoyo@fisip.unila.ac.id
}

\begin{abstract}
The government uses the participation approach in the efforts to overcome the socio-economic problem capacity within the community since it was able to increase community empowerment indirectly, even though to the probability of fake participation in the program implementation still exist. The purpose of this research is to find out the participation form that raised by the government programs, by looking at the community behaviour factors that determine the success of participation and a behaviour-based model of community participation to overcome the participation problem. The research type is descriptive with a qualitative approach through the application of several methods of data collection, in-depth interviews, secondary data studies and observations. The informants of this study were 20 people from local government, program implementers and target groups. The analysis data is using the qualitative technique. The results identified the typology of participation that emerged in the management of community participation programs in Lampung Province in the area of nonparticipation, delegation of authority and partnerships. The conditions of participation that occur driven by community behaviour factors. Consist of three factors, namely: 1) Trust or opportunity to participate; 2) Ability to participate, and 3) Willingness to participate in each activity determined by the presence or absence of the interests concerned. In the end, a behaviour-based participation management model built by adopting the concept of community engagement and personal engagement.
\end{abstract}

Keywords: community participation; government programs; community behavioral

\begin{abstract}
Abstrak
Pendekatan partisipasi nampak menjadi pilihan utama pemerintah dalam mengatasi problema kapasitas sosial ekonomi di dalam masyarakat karena dipercaya mampu meningkatkan keberdayaan masyarakat secara implikatif, meskipun dimungkinkan juga terjadinya partisipasi palsu atau formalitas demi terlaksananya program. Riset ini memiiki tujuan untuk mengetahui bentuk partisipasi yang dimunculkan dari program pemerintah, faktor perilaku masyarakat yang menjadi penentu keberhasilan partisipasi dan model partisipasi masyarakat berbasis perilaku yang dapat dimunculkan guna mengatasi permasalahan partisipasi. Tipe penelitian ini adalah tipe deskriptif dengan pendekatan kualitatif melalui penerapan beberapa metode pengumpulan data, yaitu wawancara mendalam, studi data sekunder dan observasi. Informan penelitian ini yaitu 20 orang yang berasal dari pemerintah daerah, pelaksana program dan kelompok sasaran. Teknik analisis data pada penelitian ini menggunakan metode analisis data kualitatif. Hasil riset mengidentifikasi tipologi partisipasi yang muncul dalam pengelolaan program partisipasi masyarakat di Provinsi Lampung berada pada area non participation, pendelegasian wewenang dan kemitraan. Kondisi partisipasi yang terjadi didorong juga oleh faktor perilaku masyarakat yang terdiri dari tiga wujud faktor, yaitu; 1) kepercayaan atau kesempatan untuk berpartisipasi. 2) kemampuan untuk berpartisipasi, dan 3) kemauan untuk berpartisipasi dalam setiap kegiatan ditentukan oleh ada atau tidaknya kepentingan yang bersangkutan. Pada akhirnya, model pengelolaan partisipasi berbasis perilaku dibangun dengan mengadopsi konsep community engagement dan personal engagement.
\end{abstract}

Kata kunci: partisipasi masyarakat; program pemerintah; perilaku masyarakat

\section{Introduction}

In social development, the importance of the fulfilment aspects was the society had reached the level of full participation in making decisions activities that affect their welfare and capable of implementing 
their own decisions. Participation, in this case, develops a sense of community that encourages the building of social integrity. In general, social development that relies on the growth of participation in it has implications for essential changes in development planning that were initially top-down change into bottom-up (Ahsan 2013). In realising governance in the regions, especially the implementation of a policy, the participation of local communities carried out of their own volition is necessary rather than the people's unwillingness participation. Because this is the beginning of independence and competency development in government, participation encouraged by the government also indicates there is no dominance or hegemony within it (Kleden 2004).

The government is incapable of implementing the policies effectively if it is unsupported by the people who have a variety of social, educational, economic, cultural, and sense of awareness backgrounds that influence the government development (Mansuri \& Rao 2012). In the context of participation, the community as individuals performs optimally to support government policies. Collectively, the community works together to push the government in conducting policies in order to have optimal results. Therefore, societies as an individual and collective unity have interrelations in the context of participation in the public space (Hardin 2015).

The government encourages development in the regions through several programs that have participation content. However, the difference is on the implementation of policies and programs in several sectors. For instances, in the education sector, participation appears in the form of school committee members, joint planning between the school committee (Anggraini et al. 2018). In waste management, participation takes the form of collective awareness to sort the waste, recycle and convert it into compost (Dhokhikah et al. 2015), waste bank management (Widiyanto \& Rahab 2017), poverty alleviation (Santosa 2016), improvement of education capacity (Amaliah 2015) and forest management (Sudrajat et al. 2016). In planning and organising participation also appears in infrastructure development programs in rural and urban areas (Noah \& Winoto 2017).

These various participation programs exhibit different characters, including raising fake participation. That is administrative participation in nature or even fails to hold participation at the initial stage (Muslim 2017). It also indicates the difference between organic participation (endogenous efforts by community activists to produce change) and induced participation (large-scale efforts to design participation at the local level through programs and projects) (Aga et al. 2017). In other contexts, participation also appears unable to strengthen the relationship between collective agencies and collective capabilities to drive the target groups program to carry out the participation process (Pelenc et al. 2015). In building participation, it should prioritise the people interest, which designed within the policy and actual implementation (Sudjatmoko \& Setyowati 2017).

In the scope and relations development, the implemented participation in regional scope is an interesting aspect to study. Nevertheless, if participation includes personal and group involvement, it becomes questionable why participation in government programs always facing the lack of desired for empowerment. By trying to limit the research area to the regional government in Lampung Province, there are some problem formulations in this study, namely: 1) what is the creating forms of community participation in the process of implementing local government programs?; 2) what are the potential factors of community behaviour that hinder or encourage the success of community participation in the implementation of participation programs in local governments; and 3) what is the model of community participation based on community behaviour in the process of implementing programs in local government?

Participation is one of the fundamental aspects of a democratic system (Scaff 1975). Since. It served as existence the government in order to satisfy all components of the state, where all the people could participate, even in the smallest functions of public management. It is useful that participation should be in every aspect as a general agreement in the efforts to develop the community. Active public participation is necessary for sustainable democracy and effective service delivery (Masango 2009). Participation as a prerequisite for a democratic society served as a premise, in order to shape democratic society, it should consist of institutions that capable of providing participatory space 
(Webler \& Renn 1995). Moreover, the use of authority and power to control technical decisions shows the scope, which the exclusion of the public from movements that could affect the community fate (Smith \& Blanc 1997). The public needs to influence the decision-making within the institution in a substantive way. At a further level, it is increasing the level of participation capable of making the institution better (Driskel 2017).

There are two approaches in terms of participation, namely: 1) participation comes from within the community as a goal of the democratic process. In the other side, few people are willing to approach voluntary participation in the development activities; 2 ) participation with a positive motivation that imposes the community to do something. With this approach, the community is forced to participate in the development to be able to implement and enjoy the results of better development (Mikkelsen \& Gundersen 2003). Furthermore, participation could be carried out with different levels of coercion and voluntary, as well as different levels of community activities. However, in order to achieve development success, active and voluntary participation is an ideal aspect that should be pursued (Nosenzo \& Tuffano 2017).

Community participation is unavoidable as the primary condition in the implementation of development through a self-help system. Participation also encourages and facilitates the development process. Concerning participation in development, according to Slamet (1980), he defines that community participation in providing development input. For instance, in the form of assistance from staffs, materials, funds, expertise, ideas, alternatives and satisfaction, and enjoy the development results as intended through those development goals. Meanwhile, according to Reed (2008), it is necessary to institutionalise stakeholder participation in participatory policies, which resulted in organisational culture creation. It allows the processes, where the negotiating goals exist, and results will be uncertain. In this case, the participatory process seems risky. However, if it is a rounded design, the risk might be worth to be taking. Nevertheless, from the above definition, it can be stated that community participation in development is to improve, facilitate, and guarantee the success of development efforts. The expectation from community participation is useful for the development results that are designed and carried out for their welfare. Since that, the act of community participation in development within the constructive activities context is to achieve a better condition (Nurcholis 2009).

The level of community participation in the program implementation, that the measurement is using the participation instrument from Arnstein (1969) in Gumilar (2018), which refers to the eight steps of community participation consists of 1) therapy and 2) manipulation. The categorisation at the lowest level is non-participation. The goal of this form is to "educate" and "treat" the community to participate. 3) The submission of information (informing), 4) consultation, 5) reduction of anger (placation). The third, fourth and fifth steps are "tokenism", which is a degree of participation where people are heard and allowed to think, but they cannot obtain a guarantee that decision-makers cannot consider their aspirations or wishes. According to Arnstein, if participation is limited in this degree, there seems to be the minimal possibility that there will be efforts to change the community towards better conditions. The next step consists of 6) partnership with bargaining power, 7) delegation of power, and 8) community control. The eight steps outline the concept of behaviour as the primary variable at play.

Participatory behaviour activities are related to action objectives. Behaviour is driven by an ideal to achieve specific goals. The concern individuals (Winardi 2004) generally cannot always know these specific goals consciously. It can be assessed from the form of response to the accompanying stimulus. There are two divisions of behaviour, namely: 1) closed behaviour is a person's response to a stimulus in a close form. The response or reaction to this stimulus is still limited to attention, perception, knowledge/awareness, attitudes that occur in people who receive the stimulus and have implicitly known by others, and 2) Open behaviour, that is someone's response to the stimulus in the form of real or open action. Means that the response is evident in the form of action or practice, which other people could quickly notice (Notoatmodjo 2003). 
Meanwhile, Skinner (1988) argues that behaviour is the response or reaction of a person to a stimulus (stimulation from outside). Therefore it occurs through the process of stimulus to the organism, and then the organism responds. There is two types of responses, first respondent response or thoughtful response caused by specific stimuli (stimulus). For example, the bright light causes the eyes to close. This response includes emotional behaviour. For example, hearing news of calamity, we will have a sad emotion. Second, operant response, the response that arises and develops then followed by a particular stimulus. This behaviour will encourage participation at different levels.

\section{Research Method}

The type of research in this study is descriptive by using a qualitative approach. Creswell in Herdiansyah (2010) argues that qualitative research is a process of scientific research, aiming to understand human problems in a social context by creating a thorough and sophisticated description, which presenting in reporting detail views of reports from sources information. It also carried out in natural settings without any intervention. This study also applies socio-legal analysis, which seeks to find out the application of laws and regulations regarding community participation in the implementation of programs and public policies.

Meanwhile, the focus in this research includes: 1) the categorisation of community form participation in the process of implementing programs or policies within local governments. the process analysis is by identifying the successes and failures of community participation practices that have been implemented in several government programs and policies, 2) potential factors of community behaviour that inhibit or encourage the success of community participation in the implementation of participation programs in local governments, which were analysed by identifying and describing aspects that relates to the success or failure of community participation practice in several government programs or policies, and 3) the model of community participation based on community behavior in the process of implementing local government programs by identifying, categorising, looking for connections and inferring forms of community participation and factors that hinder or encourage successful community participation in the implementation of programs or public policies.

In this qualitative research, several methods of data collection are commonly used, including in-depth interviews, secondary data studies and observations, while the data analysis technique is directed to address the formulation problems in this research. The informants in this study consisted of 20 people from local government, program implementers and target groups. In this study, a qualitative data analysis method, according to Miles \& Huberman (1994:148) using three components of analysis; using three components of analysis; data reduction, data presentation, conclusion drawing or verification. Data reduction is defined as the process of selecting, focusing on simplification, abstracting, and transformation of rough data arising from written records in the field. Presentation of data as a collection of information that gives the possibility of drawing conclusions and taking action while conclusions are part of an activity of a complete configuration where conclusions are also verified during the research.

\section{Results and Discussion}

\section{Analysis of participation forms and critical success factors for community participation programs}

In this study, three government programs selected for each local government. Those are 1) Gemma Sewu Bersenyum Manis Program in Pringsewu District; 2) National Program for Community Empowerment in Rural Self-Reliance or Program Nasional Pemberdayaan Masyarakat Mandiri Perdesaan (PNPM) in Bandar Lampung City; and 3) Health Promotion Program in East Lampung Regency.

The program was chosen purposively based on the characteristics of the adequacy resources, activities scope and the implementation format owned by each program. The Gemma Sewu Bersenyum Manis Program is the flagship program of the Pringsewu Regent whose aim is to accelerate physical and economic development and assess the success of the program. The National Program for Community Empowerment in Rural Self-Reliance (PNPM) is a government program that substantially seeks to 
reduce poverty through the concept of empowering communities and local development actors, including the Regional Government and local care groups. Therefore, the independence movement brings influence in reducing poverty and create sustainable development while the Health Promotion Program in East Lampung served as an answer to the community basic health needs because all citizens have rights to access the health services. The results of identifying the participation of the three programs are in Table 1.

Table 1.

Identification of Participation Forms in the Three Participatory Programs in Lampung Province

\begin{tabular}{|c|c|c|c|}
\hline $\begin{array}{l}\text { Activities } \\
\text { Phase }\end{array}$ & $\begin{array}{c}\text { Gema Sewu Bersenyum } \\
\text { Manis Program }\end{array}$ & $\begin{array}{c}\text { National Program for } \\
\text { Community Empowerment } \\
\text { in Rural Self-Reliance } \\
(P N P M)\end{array}$ & Health Promotion \\
\hline Planning & $\begin{array}{l}\text { Invite at least five people } \\
\text { from each neighbourhood } \\
\text { (RT) in the meeting where } \\
\text { they gave suggestions for } \\
\text { the allocation funds from } \\
\text { the district government. } \\
\text { However, the state apparatus } \\
\text { is the one who makes the } \\
\text { decision. }\end{array}$ & $\begin{array}{l}\text { The presence of the } \\
\text { community in PNPM } \\
\text { socialisation, community } \\
\text { meetings, and submission } \\
\text { proposal funding, although } \\
\text { still encountered by people } \\
\text { who did not participate for } \\
\text { personal reasons. }\end{array}$ & $\begin{array}{l}\text { Invite at least five people from } \\
\text { each neighbourhood (RT) in } \\
\text { the meeting where they gave } \\
\text { suggestions for the allocation } \\
\text { funds from the district } \\
\text { government. However, the } \\
\text { state apparatus is the one } \\
\text { who makes the decision. }\end{array}$ \\
\hline $\begin{array}{l}\text { Implemen- } \\
\text { tation }\end{array}$ & $\begin{array}{l}\text { The activity is only carried out } \\
\text { through community groups } \\
\text { (Pokmas) by creating bricks } \\
\text { and cultivating carp. The } \\
\text { funding is used to purchase } \\
\text { equipment and materials. } \\
\text { However, group members } \\
\text { forced to self-help in order } \\
\text { covering the lack of funds. }\end{array}$ & $\begin{array}{l}\text { Communities that carry out } \\
\text { activities together comes } \\
\text { from the residents where } \\
\text { the activities are carried out. } \\
\text { Such as in the making of } \\
\text { talud, drainage, construction } \\
\text { of the Health Center and } \\
\text { various PNPM Urban } \\
\text { activities that have become } \\
\text { priority activities. }\end{array}$ & $\begin{array}{l}\text { In the management } \\
\text { mechanism, the collaboration } \\
\text { carried out by the community } \\
\text { through the active } \\
\text { contribution that being paid to } \\
\text { the neighbourhood (RT) and } \\
\text { continued to the Head of the } \\
\text { Hamlet and the Treasurer of } \\
\text { healthy funds. }\end{array}$ \\
\hline Utilisation & $\begin{array}{l}\text { The brick business group } \\
\text { is a supplier of building } \\
\text { materials, while the gouramy } \\
\text { fish group runs used ponds } \\
\text { because there were no } \\
\text { funds to buy fish seeds. } \\
\text { Both activities resulted in } \\
\text { increasing their income. }\end{array}$ & $\begin{array}{l}\text { The number of residents } \\
\text { who use the results of } \\
\text { development, such as } \\
\text { clean water obtained } \\
\text { from bore wells, drainage } \\
\text { improvements, community } \\
\text { health centers that can be } \\
\text { used by the community, } \\
\text { roads (talud), these kind of } \\
\text { results could revolve the } \\
\text { economic funds that can be } \\
\text { used to help other people by } \\
\text { giving them capital to start } \\
\text { their own business }\end{array}$ & $\begin{array}{l}\text { The community uses the } \\
\text { health fund for urgent medical } \\
\text { needs through the village } \\
\text { midwife and her referral. As } \\
\text { for the number of family heads } \\
\text { who participate in healthy } \\
\text { fund activities is increasing } \\
\text { every year. }\end{array}$ \\
\hline Evaluation & $\begin{array}{l}\text { Pokmas Treasurer is the only } \\
\text { one who works on the report. } \\
\text { Because the other Pokmas } \\
\text { members claimed, they are } \\
\text { unable to finish the workload. }\end{array}$ & $\begin{array}{l}\text { The community makes a } \\
\text { report on the accountability } \\
\text { of the activities carried out, } \\
\text { however, in making the report, } \\
\text { community participation is } \\
\text { not optimal because the } \\
\text { reports only carried out by } \\
\text { one or two people and a team } \\
\text { of assistants. }\end{array}$ & $\begin{array}{l}\text { The report management } \\
\text { mechanism carried out } \\
\text { openly. Healthy fund } \\
\text { documents about cash or } \\
\text { income and expenditure } \\
\text { funds are explained in } \\
\text { detail and are transparent } \\
\text { to the village apparatus. }\end{array}$ \\
\hline
\end{tabular}

Sources: The Results of Data Analysis (2017)

Subsequent analysis of the Gema Sewu Bersenyum Manis Program shows that the form of community participation in the planning stage is limited and informative. At the implementation stage, the community can mobilize resources and funds but has weak coordination and cannot describe the program. The form of community participation in utilisation is group community which involved in a program and the status as an executor of the program. Therefore, it only affects group members and 
at the evaluation stage. It appears that only certain people are involved. The obstacles in this program include the lack of public understanding, lack of funds and weak coordination in reporting activities. It can be assumed that the Gema Sewu Bersenyum Manis Program is at the lowest participation ladder, namely therapist or informative non-participation.

$P N P M$ as one of the actor in this active participation research. Analysis of the data in the table above shows that community participation in this program is already present, although incomprehensive. Community participation through National Program for Community Empowerment in Rural Self-Reliance $(P N P M)$ is sufficient and classified as participation in the typology of delegation power. In this type of participation, the community actively conducts planning, implementation and monitoring and has the power to carry out the program by participating in each stage while the health promotion program shows that the government apparatus, accompanied by the village midwife, carries out the process and mechanism for managing healthy funds. Followed by socialisation to the community. The program has been running well, with the number of people participating in health fund activities increase for each year. The existing social capital supports the success of the empowering process and funding management mechanism in the community, which consists of high self-awareness, and a sense of solidarity and well cooperation in improving health standards. Participation in this program is on risk-taking participation, where the processes that take place and develop not only produce decisions, also resulting on thinking about the consequences of the results that relate to benefits, obstacles and implications. At this stage, participation is at the level of partnership where the government and the community are equal partners. The power has been granted, negotiations between the community and the stakeholders in terms of both decision-making, implementation, utilisation and monitoring or evaluation. From the three programs, several main factors that have roles as obstacles and driving forces the success of the participation program, that shown in Table 2.

The analysis of these factors can conclude in two aspects. The program organisers' institutions and the aspects of community behaviour that tend to not optimal support program implementation, which resulted in the creation of ineffective participation. Therefore, it needs a participation model based on community behaviour so that it can encourage the achievement of more active participation.

\section{Behavioural-based participation models in implementing government programs}

The most crucial thing in building a participation model is the need to analyse supporting community participation factors. These factors according to Soleh (2014), consists of trust or opportunities to participate which include: political will of the government or the authorities in involving the community in development activities, both at the decision making stage when planning, implementing, maintaining and utilising results. Moreover, opportunities to get access to information needed, opportunities to obtain and utilise resources for development implementation, opportunities to obtain and use technology including appropriate equipment, opportunities for organisation including access to and use of regulations, permits and procedures for activities to be carried out and opportunities to develop leadership capable of growing, mobilising, developing and maintaining participation. This first factor, in Gemma Sewu Bersenyum Manis Program as at the non-participation stage, and the condition is driven by a lack of trust or the opportunity given to participate.

Second, the ability to participate. That providing opportunities/trust to encourage community participation will be insufficient if the community itself does not have the capacity or ability to take part in every development activity. Those refers to the ability to understand and find opportunities to build or have knowledge about opportunities to improve the quality of life, the technical ability to carry out meaningful activities regarding the knowledge and mastery of technology or skills that should be possessed and the ability to solve problems that faced by utilising available resources and opportunities optimally. This second factor can be observed in the implementation of the urban PNPM program, where the community still has a weak understanding of participation in the program, as an effect there has been participating with the type of delegation of authority but still in optimal. 
Tabel. 2

Identification of factors inhibiting or driving the success of the Community Participation Program in Lampung Province

\begin{tabular}{ccc}
\hline $\begin{array}{c}\text { National Program for } \\
\text { Community Empowerment } \\
\text { in Rural Self-Reliance } \\
\text { (PNPM) }\end{array}$ & Health Promotions Program & $\begin{array}{c}\text { Gema Sewu Bersenyum } \\
\text { Manis Program }\end{array}$ \\
\hline
\end{tabular}

\begin{abstract}
Limited budget resources.
For (physical) development activities, it is felt to be lacking, and the funds provided divided into three phases, which require administrative compliance, which makes development stalled temporarily.

Low level of public

awareness

There are community groups who think that PNPM Urban is only a "project" from the government so that only people in certain groups are involved.

\section{Lack of society understanding}

The society capacity in reporting still lacks; not all the society knows formal aspects in administrative.
\end{abstract}

\section{Society is busy}

A community in urban area have difficulty to participate in each activity, even though these activities have the potential to benefit themselves.

\section{Self-Awareness and Solidarity}

High self-awareness from Responsive Apparatus individuals who participated in Responsive village the health fund activities, as well as high solidarity and good cooperation in raising health standards.

\section{The benefits}

Healthy fund activities are also beneficial for the villagers' members, besides, to be able to ease the burden when a disaster strikes

\section{Output and outcome}

This health fund activity also increases public knowledge about health, and increase the understanding of togetherness. Therefore it is necessary to maintain the health together.

\section{Society misunderstanding on Gemma Sewu Program}

The people assumed that this program as a project, so they were reluctant to get involved.

\section{Lack of fund resources}

Funds stimulant populist economic activities are felt to be lacking because these funds must be distributed to two business group

Weak Coordination between Pokmas and PMD regarding activities reports.

Sources: Researcher Analysis 2017

Third, the willingness to participate in each activity determined by the presence or absence of the interests concerned. These interests will determine people's attitude and behaviour in deciding to participate or not. A person's willingness to participate in activities related to 1) the attitude to leave the old values which are considered to hamper the improvement of quality of life, 2) the attitude and level of trust in the government/authorities, 3) the attitude to always want to get ahead of the present conditions or unsatisfied with the current situation, 4) the attitude of togetherness in solving everyday problems, and 5) the attitude of independence or self-confidence in the ability to improve the quality of life. This third factor can be observed in the implementation of health promotion programs in which people are interested in participating because they convince of their interests in better health conditions. Therefore it can be understood if the level of participation achieved is at the partnership stage.

Based on the explanation, it concludes that the factors influence the success of community participation can come from within the individual, namely will and ability, as well as from outside the individual itself such as government, economy and also legality.

\section{The model of management program in behaviour based participation}

The concepts of community engagement and personal engagement are the building blocks of behaviourbased participation management models. Personal engagement is physical, cognitive, and emotional 
self-actualisation during work. Individuals who are engaged fully understand both physically, cognitive and emotionally in the role of work Herbert (2011). Another opinion put forward by Macey \& Schneider (2008) defined engagement as: “an individual's sense of purpose and focused energy, evident to others in the display of personal initiative, adaptability, effort, and persistence directed toward organisational goals." The interpretation from Macey \& Schneider (2008) is in the sense of purpose and energy that is focused, shows personal initiative, adaptable, high efforts, and persevere towards organisational goals. Engagement means an energetic experience from involvement using personal fulfilment activities that the characters consist of energy, involvement, and professional efficacy, which are opponents of the three characteristics of burnout (Demerouti \& Bakker 2007).

Meanwhile, Albrech (2011) concluded that engagement depicts two qualities. First, a positive and energetic state of motivation that collaborates using work and clear expectations for contributing to work roles and organisational success. The definition of engagement requires an apparent disparity from constructions that better conceptualised as an antecedent or driver of engagement. From this definition, it is agreeable that engagement is desirable, has organisational goals and has psychological aspects, and attitudes that involve energy, enthusiasm, and focused effort (Herbert 2011). In line with these definitions, the engagement becomes a perspective for a person to be motivated and cooperate with the state of fulfilment of individuals characterised by energy and high mental resilience during work, enthusiasm, feeling essential and work proud, and focus on enjoying work.

On the individual dimension, building a model of participation based on community behaviour is relating to the conception of personal resources, a predictor of work engagement. Personal resources, in this case, are positive self-evaluation that has a relationship with resilience and relates to the ability of individuals to control and have a substantial impact on their environment (Herbert 2011). Personal resources reflect that positive self-evaluation determines goal setting, motivation, performance, job satisfaction, life satisfaction, and other work outcomes. That the more significant the individual's resources, the more positive the individual and self-harmony goals emerge (Herbert 2011). The keyword in this aspect is the need to strengthen self-efficacy in the design of participation programs.

The understanding of the self-efficacy concept as an individual's ability to organise and execute elements of an action needed to produce achievement (Bandura 1997). In addition, according to Bakker (2011) defines self-efficacy as a form of feeling for adequacy, efficiency, and self-ability to cope with life. (Baron \& Bryne 1987) Express that self-efficacy as an individual's assessment of his ability or competence in carrying out a task, achieving a goal, and producing something. Bandura (1997) also suggested that psychological processes in self-efficacy that play a role in humans consist of four processes: cognitive process, motivational, affection, and selection process. It is essential to accommodate these four processes within the program that design based on community participation.

In the community dimension, community engagement is a series of stages to involve the community to be active in overcoming problems; for example, building coalitions and facilitating community workshops (Swainston \& Summerbell 2008). According to them, there are three main types of community involvement initiatives, which consist of several initiatives, namely: 1) region-based initiatives that refer to social and economic disparities; 2) people-based initiatives to involve marginalised populations and 3) coalition-based initiatives that draw on the strengths of interest groups. The typology of the initiative appears varied in various participation programs that built with the characteristics and objectives. The initiative will be included in the involvement, consultation until the authority delegated in planning and design in carrying out joint program governance.

In the aspect of community engagement, the design of participation programs, there are several vital points to ensure successful application of the model. Those are: 1) a facilitator who will advertise, recruit, and select community organisations to participate; provide and support a staff team; and encourage inter-community and intra-community participation, 2) host community organisations that have good relations with the target community, 3) meaningful, time-limited and easy to manage tasks. It can be one or all of the circles in the model diagram, which connects communities and institutions in fair employment. 4) training of community organisation members as project coordinators, 5) project 
support workers who provide support to the community, as directed by the facilitator, 6) financial support for project activities and personnel, and 7) steering group which must include local planners and service/program providers. In the context of managing community participation programs, a model that covers both dimensions; the directions of personal dimension and the community dimension are towards changing individual and group attitudes from within themselves. Because driving changes are from the internal self, and the organisation will have a long-term effect. From this description, the behaviour-based participation management model explains as in Figure 1.

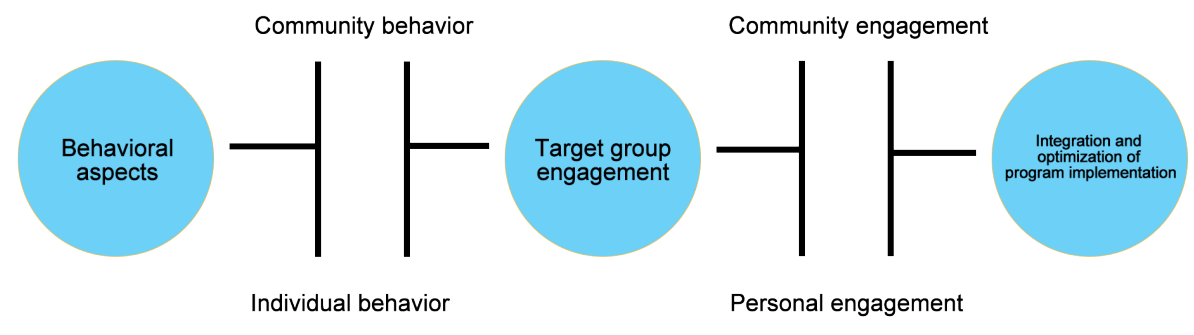

Figure 1.

The model of management program in behaviour based participation

This model focuses on strengthening aspects of community behaviour in participatory programs where the behavioural aspects include community and individual behaviour that involved in the program. Both aspects are essential because participatory programs focus on group empowerment, which expects to have implications for individuals involved in the program. The intended community management consists of facilitative capacity, organizational relations, and division of tasks, training and budget management. While in Personal engagement includes strengthening cognitive capacity, motivation and affection of individuals in the target group. The expectation of strengthening these two capacities is to have implications for the integration and optimisation of participatory program implementation. Covering these two aspects will drive the target group of the program. This model aims to intervene in program design that is less successful in creating optimal community participation by maximizing the behavioural aspects of individuals and the community. Individual and group behaviour that is well understood by the program design that encourages acceptance and the direction of creating participation to reach the maximum level. Therefore, this model is worth testing through a social experiment that simulates the program by strengthening the engagement dimension.

\section{Conclusion}

The typology of participation that emerged in the management of three community participation programs in Lampung Province is in the areas of non-participation, the delegation of authority and partnership. It based on variations in the implementation of programs that have different implementation designs. In well-designed programs, such as PNPM Urban has reached the level of delegation of authority even though it not optimal in driving community participation. While the programs that are not well-designed, such as the Gemma Sewu Bersenyum Manis Program, show a level of non-participation due to program design that is more project-oriented so that participation aspects of are not fully developed.

The conditions of participation that occurred in the implementation of the three programs also driven by three factors, namely; 1) Trust or opportunity to participate; this factor can be observed in the Gemma Sewu Bersenyum Manis Program that is at the non-participation stage, and the condition happens because a lack of trust or opportunities is given to participate, 2) The ability to participate. This second factor can be observed in the implementation of the urban PNPM program, where the community still has a weak understanding of participation in the program so that in the end, though there has been participating with the type of delegation of authority, it has not been optimal, and 3) In determining the willingness to participate in each activity is by the presence or absence of the 
interests concerned. The observation in the implementation of health promotion programs is towards where people are interested in participating because they convinced of their interests in better health conditions. Therefore, it can be understood if the level of participation achieved at the partnership stage.

Behaviour-based participation management models built by adopting the concepts of community engagement and personal engagement. On the individual dimension, building a model of participation based on community behaviour is related to the conception of personal resources, which is a predictor of work engagement. The keyword in this concept is the need to strengthen self-efficacy in the design of participation programs. Four behavioural processes in self-efficacy play a role in humans, consists of cognitive, motivational, affection, and selection processes. Four processes that need accommodating in the design of community participation based programs. On the community dimension, the community engagement approach is a series of steps to actively involve the community in handling problems, such as forming coalitions or facilitating community workshops. In the aspect of community engagement in the design of participation programs, there are some crucial points to ensure successful application of the model, namely facilitators, organizational relations, task management, training, support staff and funding.

\section{References}

Aga DA, Noorderhaven N, \& Vallejo B (2018) Project beneficiary participation and behavioural intentions promoting project sustainability: The mediating role of psychological ownership. Development Policy Review 36 (5):527-546.

Albrech SL (2011) Handbook of employee engagement: Perspectives, issues, research and practice. Hum Resour Manag Int Dig 19 (7). https://www.emeraldinsight.com/doi/full/10.1108/ hrmid.2011.04419gaa.019.

Amaliah D (2015) Pengaruh partisipasi pendidikan terhadap persentase penduduk miskin. 2 (3):9.

Anggraini FL, Hanurawan F, \& Hadi S (2018) Partisipasi komite sekolah pada kegiatan ekstrakurikuler. Jurnal Pendidikan: Teori, Penelitian, \& Pengembangan 3 (5):544-551. DOI: http://dx.doi. org/10.17977/jptpp.v3i5.10962.

Bandura (1997) Self-efficacy: The exercise of control. USA: Mac Millan; 1997.

Bakker AB (2011) An evidence-based model of work engagement. Curr Dir Psychol Sci 20 (4):265269.

Baron R \& Bryne D (1987) Social psychology: Understanding human interaction. New York: Allyn \& Bacon; 1987.

Demerouti E \& Bakker AB (2007) The job demands resources model: State of the art. J Manag Psychol 22 (3):309-328.

Dhokhikah Y, Trihadiningrum Y, \& Sunaryo S (2015) Community participation in household solid waste reduction in Surabaya, Indonesia. Resour Conserv Recycl 102:153-62.

Driskel D (2017) Creating Better Cities with Children and Youth: A Manual for Participation. https:// www.taylorfrancis.com/books/e/9781315071930.

Kleden I (2004) Masyarakat dan negara: sebuah persoalan. Penerbit Agromedia Pustaka, pp. 290.

Gumilar I (2018) Partisipasi masyarakat pesisir dalam pelestarian ekosistem hutan mangrove (Studi kasus di Kabupaten Indramayu Jawa Barat). Sosiohumaniora 20 (2):145-153.

Hardin R (2015) Collective Action. New York: RFF Press. https://www.taylorfrancis.com/ books/9781315044330.

Herbert M (2011) An Exploration of the Relationships Between Psychological Capital (Hope, Optimism, Self-Efficacy, Resilience), Occupational Stress, Burnout and Employee Engagement. Thesis, Stellenbosch University. https://scholar.sun.ac.za:443/ handle/10019.1/17829.

Herdiansyah H (2010) Metodologi Penelitian Kualitatif untuk Ilmu-Ilmu Sosial. Jakarta: Salemba Humanika. 
Macey WH, Schneider B. (2008) The Meaning of Employee Engagement. Ind Organ Psychol 1 (1):3-30.

Mansuri G \& Rao V (2012) Localizing Development. https://elibrary.worldbank.org/doi/ abs/10.1596/978-0-8213-8256-1.

Masango RS (2009) Public participation : An imperative for sustainable democracy and effective service delivery. J Public Adm 1 (44):123-132.

Mikkelsen A \& Gundersen M (2003) The effect of a participatory organizational intervention on work environment, job stress, and subjective health complaints. International J Stress Management 10 (2):91-110.

Miles \&Huberman(1994) Qualitative DataAnalysis:AnExpanded Sourcebook. London. Sage, pp 148.

Muslim A (2017) Analisis kegagalan program nasional pemberdayaan masyarakat dalam membangun kemandirian masyarakat miskin (Studi kasus di Provinsi Daerah Istimewa Yogyakarta, Jawa Tengah, dan Jawa Timur). Jurnal Penyuluhan 13 (1):79-87.

Nosenzo D \& Tufano F (2017) The effect of voluntary participation on cooperation. Jurnal Econ Behaviour Organ 142:307-319.

Notoatmodjo S (2003) Pendidikan dan perilaku kesehatan. Jakarta: rineka cipta, 16, 15-49. Jakarta: Rineka Cipta; 2003.

Nurcholis H (2009) Perencanaan Partisipatif Pemerintah Daerah. Grasindo, pp. 192.

Pelenc J, Bazile D, \& Ceruti C (2015) Collective capability and collective agency for sustainability: A case study. Ecological Economics 118:226-239.

Reed MS (2008) Stakeholder participation for environmental management: A literature review. Biol Conserv. 2008 Oct 1;141(10):2417-31.

Santosa SH, Prihatini D, Purwanto A, Jumiati A, \& Susilo D (2016) Pengembangan Pola Kemitraan dalam Rangka Pengentasan Kemiskinan di Jawa Timur. UNEJ E-Proceeding, pp. 601-611.

Scaff LA (1975) Two Concepts of Political Participation. West Polit Q. 1975 Sep 1;28(3):447-62.

Skinner BF (1988) The Selection of Behavior: The Operant Behaviorism of B. F. Skinner: Comments and Consequences. CUP Archive, pp. 596.

Slamet (1989) Konsep-konsep dasar partisipasi sosial. Yogyakarta: Pusat Antar Universitas Studi Sosial Universitas Gadjah Mada.

Smith DM \& Blanc M (1997) Grass-Roots Democracy and Participation: A New Analytical and Practical Approach. Environ Plan Soc Space. 1997 Jun 1;15(3):281-303.

Soleh (2004) Dialektika pembangunan dengan pemberdayaan. Jakarta: Fokus Media.

Sudjatmoko FX \& Setyowati ND (2017) Transformasional kepentingan rakyat dalam perspektif pemberdayaan masyarakat bagi penanganan kemiskinan sosial melalui Government Social Responsibility (GSR). Masyarakat, Kebudayaan dan Politik 30 (1):94-102.

Sudrajat A, Hardjanto, \& Sundawati L (2016) Farmer Participation on Sustainable Private Forest Management: Case of Cikeusal and Kananga Villages, Kuningan District Partisipasi Petani dalam Pengelolaan Hutan Rakyat Lestari. J Silvikultur Trop 7 (1). http://ilkom.journal.ipb. ac.id/index.php/jsilvik/article/view/13289.

Swainston K \& Summerbell C (2008) The effectiveness of community engagement approaches and methods for health promotion interventions. Methodology 17 (31).

Webler T \& Renn O (1995) A Brief Primer on Participation: Philosophy and Practice. In: Renn O, Webler T, Wiedemann P, editors. Fairness and Competence in Citizen Participation: Evaluating Models for Environmental Discourse. Dordrecht: Springer Netherlands; 1995 [cited 2019 May 17]. p. 17-33. (Technology, Risk, and Society). https://doi.org/10.1007/978-94-011-0131-8_2.

Widiyanto AF \& Rahab R (2017) Community participation in bank of garbage: Explorative case study in Banyumas regency. Masyarakat, Kebudayaan dan Politik 30 (4):367-76.

Winardi J (2004) Motivasi dan Pemotivasian Manajemen. Jakarta: PT. Raja Grafindo Persada. 